\title{
Audit Typologies used by Communication Public Relations Directors and Agencies: A COMparative ANALYSis, SPAin - ECM
}

\author{
Kathy Matilla; Guillem Marca-Francés \& Andréa Oliveira \\ kathyms@blanquerna.url.edu; guillem.marca@uvic.cat; andrea.oliveira@udg.edu \\ Universidad Ramon Llull / Universidad de Vic. Sagrada Familia/ Universidad de Gerona \\ Facultad de Comunicación Blanquerna, Universidad Ramon Llull. Valldonzella, 23, 08001 Barcelona (España)
}

\begin{abstract}
The double applied research conducted in Spain with Dircom partners -the association of communication directors of major companies in the country- and with public relations and communications agencies/consultancies show the trend that, today, in the Spanish professional practice, the instrumental orientation (tactical) is prevalent, correlated with what happens in other European countries (ECM-European Communication Monitor). This can be deduced from the assignment and the prevalent use of audits clearly associated with the measurement of Output results.
\end{abstract}

KEYWORDS

Audit; director of communication, evaluation, public relations, research, strategic planning

\section{INTRODUCTION}

During the first quarter of 2013 we carried out, in parallel, two studies with identical questionnaires, which were applied in two different although complementary groups: on the one hand, Spanish communication and public relations (PR) agencies/consultants, and on the other, their clients. Both groups, dependent on each other and, therefore, being in a dialogical relationship, constitute key players in the professional practice of the process of communication and public relations. Therefore, we found that it was interesting to formulate the same questions to both of them, with the aim of observing if there were any correlations or deviations in the responses and in order to deepen the understanding of the behaviour of both groups in their professional collaboration routines, specifically bounded to the use of strategic research. We also wanted to see if these routines were developed based on the principles of the international literature on the object of study.

In our literature review we have not been able to locate any applied research that has been carried out in Spain to specifically study these particular aspects of design and strategic development carried to professional practice. Hence, we could consider our empirical work as a contribution that perhaps may be of interest to the segment of the scientific community that wishes to contribute to the setting of a state of the art on the object of study in Spain.

Specifically, we wanted to know which type of audits was declared be used by both groups in the development of their strategic plans. For this purpose, we conducted a 
systematic search of items directly related to the reports published so far in various editions of the pan-European study ECM-European Communication Monitor (2007-2012), which are described later.

The main objective was focused on finding out specifically which were the most used audits and which methods of evaluation were employed more assiduously in the fieldworks developed by both groups. Our secondary objective, derived from the main one, allowed us to know, in depth, the quality of the work and the quality of professional relationships between both strategic actors of the communication process.

\section{Dircom, THE SPANISH ASSOCIATION OF COMMUNICATION DIRECTORS}

According to its corporate website (May 2014), Dircom groups communication managers of major Spanish companies and institutions as well as the heads of communication consultancies. Dircom's vision is to evaluate the role of communication and 'dircoms', and it pursues four strategic areas: recognition, professional development, networking and CSR. Its nearly 830 members are grouped in 8 regional offices: Andalusia, Aragon, Asturias, Canary Islands, Catalonia, Castile and León, Valencia and Galicia.

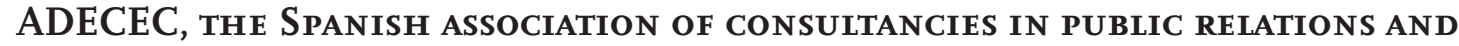 COMMUNICATION}

In the corporate website of the Association of Consultancies in Public Relations and Communication-ADECEC (May 2014), it appears recorded its founding in January 1991 by a group of executives from leading public relations and communication consulting firms in Spain, to spread the practice of strategic consulting. ADECEC acts with a vocation of employers of the sector, as it integrates the major public relations and communication agencies/consultancies in Spain, both in invoicing and in number of employees. Its mission is to dignify the profession and contribute to the growth of the practice of public relations and corporate communication in the Spanish territory.

\section{Literature Review AND THE ECM-European CommunicAtion Monitor}

In 2007, the EACD-European Association of Communication Directors and the EUPRERA-European Public Relations Education and Research Association boosted together the annual edition of a transnational macro-study, the ECM-European Communication Monitor (Zerfass, Van Ruler, Rogojinaru, Verçiç \& Hamrefors, 2007), that will be repeated, continuously, year after year, until 2013, in which it has achieved its seventh edition (Zerfass, Tech, Verhoeven, Verçiç \& Moreno, 2008; Zerfass, Tech, Verhoeven, Verçiç \& Moreno, 2009; Zerfass, Tech, Verhoeven, Verçiç \& Moreno, 2010; Zerfass, Tech, Verhoeven, Verçiç \& Moreno, 2011; Zerfass, Verçiç, Verhoeven, Moreno \& Tech, 2012; and Zerfass, Moreno, Tench, Verçiç \& Verhoeven, 2013 ).

' 'Dircom' is a diminutive of director of communication and is commonly used in Spain and France to refer to this leading role. We will use this term from now on. 
Spain has been incorporated for the first time to the ECM in the 2012 edition. Since this is a reference study in Europe and in Spain we have not found trace of applied research on our object of study, we will use the various editions of the European research as a theoretical framework.

According to its corporate website, the ECM is an annual survey on future trends in communication management and public relations and the largest transnational survey on strategic communication worldwide. Almost 2,200 professionals from 42 countries participated in 2012, and 2,710 from 43 countries in 2013. Their research topics vary year after year.

Processing the strategic activity of participants in the various editions analyzed of the ECM the data show that, with respect to the evaluation practice, $84.0 \%$ of respondents measured the impact of their messages in the mass media (Outputs $72.5 \%$ in 2008; $82.3 \%$ in 2010 ), compared to the $53.9 \%$ who reported doing so on its stakeholders (Outcomes $38.7 \%$ in $2008 ; 48.1 \%$ in 2010 ), the $46.9 \%$ on the cost of the projects (Inputs $27.7 \%$ in 2008; $47.7 \%$ in 2010) and the $34.4 \%$ on business objectives (Outflows $32.9 \%$ in 2008; $25.0 \%$ in 2010) declared to focus particularly on a part of the communication process, specifically the "clipping and media monitoring response" (84.0\% in 2008, 82.3\% in 2010), followed by the use of the intranet and the internet (64.0\% in 2008; 69.7\% in 2010).

We also noted that, compared to "the up-to-date framework for communication measurement issued by PR associations and controller associations (DPRG/ICV - Deutsche Public Relations Gesellschaft/ Internationaler Controller Verein, 2009 and Zerfass, 2010)", the preponderance of external evaluation (Output) is evident, followed by exploration of the perceptions of stakeholders (Outcome).

As for the needs of training and qualification expressed by the European participants, we note the following items, which are kept in stable rates over the past seven years: "developing communications plans linked to business strategies" (44.0\% in 2011; $43.6 \%$ in $2010,47.3 \%$ in $2009 ; 45.4 \%$ in 2008 ) and "research and measurement methods (11\% in 2009 and establishing methods to evaluate Communications" $16.1 \%$ in $2008 ; 17.2 \%$ in $2010 ; 16.3 \%$ in 2011 ).

In the 2008 edition it was concluded that: "agencies provide an ability to quantify results (17.9\%)", and that: "the agencies think that they are engaged because of strategic ad/or market insight and experience $(8.0 \%)$ but only $41.6 \%$ of their clients do so". It was also verified that European customers were less dependent on agencies than in the United States of America, in operational and strategic terms; that European agencies overestimated their abilities in all areas of strategic support; and that the investment of both groups in continuing education, applied research and long-term cooperation with academic research was still very low in Europe.

In 2010, 49.2\% of respondents stated that: "We help adjust organisational strategies"; the $72.1 \%$ that: "We build immaterial assets"; and the $62.5 \%$ that: "We feel responsible for helping to define business strategies by adding the communicative dimension to strategy formulation" (+1.8\% compared to 2009).

Also in 2010, $69.7 \%$ of European managers of functional departments stated to be responsible of the planning and the evaluation of Communications (the $74.4 \%$ in 
Southern Europe). With regard to planning procedures, they concluded that the situation could be improved significantly, since a basically instrumental level was detected: "strategies and plans for single instruments $(72.6 \%)$; overall Communication strategy $(6.2 \%)$; strategies for major disciplines/stakeholders (62.4\%); strategies and plans for specific challenges (57.7\%) and monitoring strategies (35.7\%)".

In the 2011 edition, about strategic aspects of professional practice, the data show that: "PR is no longer regarded as a suitable label for the profession compared to other concepts: $61.3 \%$ Strategic Communication". $90.8 \%$ of the participants declared: "We focus and supporting business goals by planning and executing Communication" $(+5.4 \%$ compared to 2010 , and $+6.0 \%$ compared to 2009 ) and that: "We feel responsible for helping to define business strategies" ( $+8.3 \%$ compared to 2010 and $+10.1 \%$ compared to 2009 ).

Also, participant practitioners stated collaborating with "Strategy and Organisational Development Unit" of organizations in $61.7 \%$ of cases. They concluded that $42.0 \%$ of the departments of communication of the sample did not have yet "Tools for monitoring stakeholder communications on the social web," compared to the $24.7 \%$ who aimed to implant them the same year, and a $33.3 \%$ that already had them. Only $3.24 \%$ of participants reported being able to develop social media strategies.

Participants in the 2012 ECM study (Zerfass, Verçiç, Verhoeven, Moreno \& Tench, 2012) were distributed as it follows: $78.4 \%$ 'dircoms' and $21.6 \%$ agencies/consultancies, and results related to our object of study indicate that a large majority of the respondents state that a lack of understanding of communications practice within the top management $(84 \%)$ and the difficulties of the profession itself it prove the impact of communication activities on organization goals (75\%) are the main barriers for further professionalization of the practice. So the key challenges for European communication professionals are to explain communication function to top management and to prove the value of communication for organisations, which may be at the origin of some of the methodological shortages and violations that have been identified in this study, especially when taking into account that: "For decades now, Communications Management and Public Relations is transforming itself from an operational practice of preparing, producing and disseminating Communications materials into a full Strategic Management function, which includes speaking as well as consulting as well as executing" (Zerfass, Verçiç, Verhoeven, Moreno \& Tench, 2012: 43). This requires technical recycling and renovations that probably are not yet consolidated among professionals, in line with what was stated in the 2012 ECM study:

[practitioners] are clearly reaching their limits because the complexity of communication is increasing [...] These changes in the environment are requiring communication professionals to reconceptualise and reorganise that they do. Although the majority of productive time still goes to operational communication (talking to colleagues and media, writing texts, monitoring, organising events, etc.) this does not account for more than $37 \%$ of typical week. Managing activities related to planning, organising, leading staff, evaluating strategies, justifying spending and preparing for crises take 
$29 \%$ of the time. Reflective communication management, aligning communication, the organisation/client and its stakeholders take $19 \%$ and coaching, training and educating members of the organisation or a client takes almost $15 \%$. As expected, there are significant correlations with the position of the communicator in the organisational hierarchy, with the influence of the communication function (having more influence on top management correlates with more reflection and less operations) (Zerfass, Verçiç, Verhoeven, Moreno and Tench, 2012: 43).

In the 2012 ECM edition, a recorded European trend appears: "media relations professionals perform the largest portion of operational work, while practitioners engaged in governmental relations, public affairs and lobbying spend more time for reflective activities" (Zerfass, Verçiç, Verhoeven, Moreno \& Tench, 2012: 43).

It also confirmed that much work is still needed to improve professional practice in Europe, since "As professional communicators are moving from mostly operational to more managerial, educational and reflective levels, building competencies and skills is the next big challenge both for individuals and organisations (Tench, 2012; Sha, 2011; Jeffrey \& Brunton, 2011)" (Zerfass, Verçiç, Verhoeven, Moreno \& Tech, 2012: 77).

\section{RESEARCH QUESTIONS}

To achieve our objectives, we set just one research question, in order to compare the results between the responses of both groups analyzed and, in parallel, to check whether there was correspondence or discrepancy with the results of the various editions of ECM that, as we discussed above, we will use for the referential empirical comparison.

(RQ1) Which are the most common types of audits used by directors of communication and their agencies/consultancies in Spain?

\section{MeTHODOLOGY}

The study design consisted of a double questionnaire with 4 sections and 6 questions, based on hypotheses and instruments derived from a previous research (AUTHOR) and literature and it compares the results obtained from two different groups (communication directors and communication and public relations agencies/consultancies), using a self-administered questionnaire, applied in Spain during the first quarter of 2013.

The entire database of active professionals registered at the Dircom ${ }^{2}$ association of communication directors was included. Specifically, the association comprised a total amount of 826 individuals at the time we applied the questionnaire, distributed as it follows: $53.0 \%$ were corporate communication directors; $14.0 \%$ were directors of communications and public relations agencies and consultancies; and $8.0 \%$ were communication directors of non-profit organizations (NGOs), while the rest of the partners $(25.0 \%)$ was

\footnotetext{
${ }^{2}$ Data provided by Dircom on 13th Feb. 2013.
} 
configured by: university professors-doctors specialized in communications and public relations (6.0\%); self-employed professionals (7.0\%); knowledge partners (9.0\%); and young partners (3.0\%).

As we have seen, $75.0 \%$ of members corresponded exactly to the desired profile, namely those professionals who were responsible for decision-making in the strategic domain, both directors of communication (dircoms) of companies and non-profit organizations, as well as top leaders of agencies/consultancies. It is interesting to note the coincident fact that they belong to the same professional profile of the participants of the various editions analyzed of the ECM (2007, 2008, 2009, 2010, 2011, 2012 and 2013).

In what refers to the agencies/consultancies, the questionnaire was administered to a sample of 231 participants, which was a database of own elaboration that included the 20 agencies/consultancies associated to the employers ADECEC-Association of Consulting Companies in Public Relations and Communication, which accounted the 23.1\% of the estimated total universe in the report of Torres and Carrera (2011).

The questionnaire used in our double study was almost identical to the one used by Matilla in 2007, also analyzed by Matilla e Marca (2012: 825-830), but this time validated using pre-test by 5 academic experts in the first instance, and right after, by 34 working professionals.

In both cases, we applied the web questionnaire through personalized invitation sent by email, thus ensuring the anonymity of responses. This included a link to a questionnaire with closed questions, from which we processed results automatically. The statistical data processing was performed using the statistical online package SPSS v14 for descriptive and analytical purposes.

The demographics show that, from the 826 members of Dircom, a $19.37 \%$ responded. The dissemination of the link was carried out in three consecutive phases (13th, 20th and 27th February 2013), being permanently active online on the Weekly Bulletin of the association during that period. This percentage can be considered as very satisfactory, since according to the association itself, weekly online surveys through the Bulletin rarely exceed $8-9 \%$ of respondent partners.

On their behalf, from the 231 agencies/consultancies that were sampled, the half responded (50.64\%). The questionnaire, distributed by email also in three consecutive waves (between the 23rd January 2013 and the 6th February 2013), was sent only and in all cases to the email address of the hierarchical chief of each agency/consultancy, whether it was the headquarters or one or more regional offices located in other Spanish cities, if applicable.

We believe that results obtained from the research of 'dircoms' should be considered only as trends, since not all communication and public relations directors in Spain are associated with Dircom and, therefore, they constitute a study sample but not the entire universe, which could have provided representative data. The same consideration applies to the study of the agencies/consultancies. 


\section{RESULTS}

In our analysis we have presented the results in two tables, including the percentages of the various responses, with a $95 \%$ confidence interval $(\mathrm{Cl})$.

Key issues analyzed focused in the proceedings on usages of strategic research, which were subjected to a detailed analysis: the different types of audits more frequently used by both groups.

\begin{tabular}{|c|c|c|c|c|}
\hline & \multicolumn{2}{|c|}{$\begin{array}{c}\text { Preliminary Research } \\
\qquad \begin{array}{c}n=43 \\
n(\%) \\
95 \% \mathrm{Cl}\end{array}\end{array}$} & \multicolumn{2}{|c|}{$\begin{array}{l}\text { Evaluation Research } \\
\qquad \begin{array}{c}\mathrm{n}=76 \\
\mathrm{n}(\%) \\
95 \% \mathrm{Cl}\end{array}\end{array}$} \\
\hline \multicolumn{5}{|l|}{ Outputs } \\
\hline Publicity Audit & $35(81,40 \%)$ & $69,77-93,03$ & 75 (98,58\%) & $95,94-101,22$ \\
\hline ०\% to $25 \%$ & ० (00,00\%) & - & $\circ(00,00 \%)$ & - \\
\hline $26 \%$ to $50 \%$ & $1(2,33 \%)$ & $-2,18-6,84$ & $1(1,31 \%)$ & $-1,24-3,88$ \\
\hline $51 \%$ to $75 \%$ & $1(2,33 \%)$ & $-2,18-6,84$ & $\circ(00,00 \%)$ & - \\
\hline $76 \%$ to $100 \%$ & $33(76,74 \%)$ & $64,11-89,37$ & $74(97,37 \%)$ & $93,77-100,96$ \\
\hline Events Audit & $29(67,44 \%)$ & $53,43-81,44$ & $72(94,74 \%)$ & $89,72-99,75$ \\
\hline o\% to $25 \%$ & $\circ(00,00 \%)$ & - & $\circ(00,00 \%)$ & - \\
\hline $26 \%$ to $50 \%$ & $1(2,33 \%)$ & $-2,18-6,84$ & $\circ(00,00 \%)$ & - \\
\hline $51 \%$ to $75 \%$ & $1(2,33 \%)$ & $-2,18-6,84$ & $1(1,31 \%)$ & $-1,24-3,88$ \\
\hline $76 \%$ to $100 \%$ & $27(62,80 \%)$ & $48,36-77,24$ & וד (93,42\%) & $87,84-98,99$ \\
\hline \multicolumn{5}{|l|}{ Outtakes } \\
\hline Perceptions Audit & $17(39,53 \%)$ & $24,91-54,14$ & $17(22,37 \%)$ & $13,00-31,73$ \\
\hline O\% to $25 \%$ & $6(13,95 \%)$ & $3,6-24,3$ & $5(6,58 \%)$ & 1,00-12,27 \\
\hline $26 \%$ to $50 \%$ & $1(2.33 \%)$ & $-2,18-6,84$ & $2(2.63 \%)$ & $-0,96-6,22$ \\
\hline $51 \%$ to $75 \%$ & $1(2,33 \%)$ & $-2,18-6,84$ & $1(1,31 \%)$ & $-1,24-3,88$ \\
\hline $76 \%$ to $100 \%$ & $9(20,95 \%)$ & $8,79-33,11$ & $9(11,85 \%)$ & 4,57-19,10 \\
\hline \multicolumn{5}{|l|}{ Outcomes } \\
\hline Opinions Audit & $30(69,77 \%)$ & $56,04-83,49$ & $37(48,68 \%)$ & $37,44-59,91$ \\
\hline ०\% to $25 \%$ & $7(16,27 \%)$ & $5,24-27,3$ & $15(19,74 \%)$ & $10,79-28,68$ \\
\hline $26 \%$ to $50 \%$ & $6(13,95 \%)$ & $-2,18-6,84$ & $6(7,90 \%)$ & $1,84-13,96$ \\
\hline $51 \%$ to $75 \%$ & $2(4,65 \%)$ & $-1,54-10,84$ & $4(5,26 \%)$ & $0,24-10,27$ \\
\hline $76 \%$ to $100 \%$ & $15(34,89 \%)$ & $20,65-49,13$ & $12(15,79 \%)$ & $7,59-23,98$ \\
\hline Attitudes Audit & $5(11,63 \%)$ & $2,04-21,21$ & $4(5,26 \%)$ & $0,24-10,27$ \\
\hline ०\% to $25 \%$ & $\circ(0,00 \%)$ & - & $\circ(0,00 \%)$ & - \\
\hline $26 \%$ to $50 \%$ & $\circ(0,00 \%)$ & - & $\circ(0,00 \%)$ & - \\
\hline $51 \%$ to $75 \%$ & $\circ(0,00 \%)$ & - & $\circ(0,00 \%)$ & - \\
\hline $76 \%$ to $100 \%$ & $2(4,65 \%)$ & $-1,54-10,84$ & $4(5,26 \%)$ & $0,24-10,27$ \\
\hline \multicolumn{5}{|l|}{ Outflows } \\
\hline Crisis Audit & $34(79,07 \%)$ & $66,89-91,25$ & $52(68,42 \%)$ & $57,97-78,87$ \\
\hline ०\% to $25 \%$ & $10(23,25 \%)$ & $10,62-35,87$ & $24(31,58 \%)$ & $20,37-42,78$ \\
\hline $26 \%$ to $50 \%$ & $5(11,63 \%)$ & $2,04-21,21$ & $6(7,90 \%)$ & $1,84-13,96$ \\
\hline $51 \%$ to $75 \%$ & $3(6,98 \%)$ & $-0,63-15,59$ & $4(5,26 \%)$ & $0,24-10,27$ \\
\hline $76 \%$ to $100 \%$ & $14(32,55 \%)$ & $18,54-46,55$ & $18(23,68 \%)$ & $14,12-33,23$ \\
\hline
\end{tabular}

Table 1: DIRCOM STUDY - Types of Audits ordered to the agency/consultancy Source: own elaboration 


\begin{tabular}{|c|c|c|c|c|}
\hline & \multicolumn{2}{|c|}{$\begin{array}{c}\text { Preliminary Research } \\
\mathbf{n = 2 1} \\
\mathbf{n}(\%) \\
95 \% \mathrm{Cl}\end{array}$} & \multicolumn{2}{|c|}{$\begin{array}{l}\text { Evaluation Research } \\
\qquad \begin{array}{c}\mathrm{n}=76 \\
\mathrm{n}(\%) \\
95 \% \mathrm{Cl}\end{array}\end{array}$} \\
\hline Publicity Audit & $16(76,19 \%)$ & $57,97-94,40$ & $76(100,00 \%)$ & - \\
\hline ०\% to $25 \%$ & ० (00,00\%) & - & ० (००,००\%) & - \\
\hline $26 \%$ to $50 \%$ & ० (o०,००\%) & - & ० (0o,००\%) & - \\
\hline $51 \%$ to $75 \%$ & ० (00,००\%) & - & ० (००,००\%) & - \\
\hline $76 \%$ to $100 \%$ & $16(28,75 \%)$ & $9,24-47,89$ & $76(100,00 \%)$ & - \\
\hline Events Audit & $4(19,05 \%)$ & $2,25-35,84$ & וד (93,42\%) & $87,84-98,99$ \\
\hline ०\% to $25 \%$ & ० (0०,००\%) & - & ० (0०,००\%) & - \\
\hline $26 \%$ to $50 \%$ & ० (0०,००\%) & - & ० (0o,००\%) & - \\
\hline $51 \%$ to $75 \%$ & ० (0o,००\%) & - & ० (0o,००\%) & - \\
\hline $76 \%$ to $100 \%$ & $4(19,05 \%)$ & $2,25-35,84$ & וד) (93,42\%) & $87,84-98,99$ \\
\hline \multicolumn{5}{|l|}{ Outtakes } \\
\hline Perceptions Audit & $6(28,57 \%)$ & $9,24-47,89$ & $6(28,57 \%)$ & $18,41-38,72$ \\
\hline o\% to $25 \%$ & $1(4,76 \%)$ & $-4,34-13,86$ & $1(1,32 \%)$ & $-1,24-3,88$ \\
\hline $26 \%$ to $50 \%$ & $1(4,76 \%)$ & $-4,34-13,86$ & $1(1,32 \%)$ & $-1,24-3,88$ \\
\hline $51 \%$ to $75 \%$ & $\circ(0,00 \%)$ & - & $\circ(0,00 \%)$ & - \\
\hline $76 \%$ to $100 \%$ & $4(19,05 \%)$ & $2,25-35,84$ & $4(5,26 \%)$ & $0,24-10,27$ \\
\hline \multicolumn{5}{|l|}{ Outcomes } \\
\hline Opinions Audit & $9(42,86 \%)$ & $21,69-64,02$ & $13(17,11 \%)$ & $8,64-25,57$ \\
\hline ०\% to $25 \%$ & $2(09,52 \%)$ & $-3,03-22,07$ & $1(1,32 \%)$ & $-1,24-3,88$ \\
\hline $26 \%$ to $50 \%$ & $4(19,05 \%)$ & $2,25-35,84$ & $6(7,90 \%)$ & $18,41-38,72$ \\
\hline $51 \%$ to $75 \%$ & $\circ(0,00 \%)$ & - & $2(2,63 \%)$ & $-0,96-6,22$ \\
\hline $76 \%$ to $100 \%$ & $3(14,29 \%)$ & $-0,67-29,25$ & $4(5,26 \%)$ & $0,24-10,27$ \\
\hline Attitudes Audit & $2(9,52 \%)$ & $-3,03-22,07$ & $2(2,63 \%)$ & $-0,96-6,22$ \\
\hline ०\% to $25 \%$ & $\circ(0,00 \%)$ & - & ० (o,००\%) & - \\
\hline $26 \%$ to $50 \%$ & $\mathrm{O}(0,00 \%)$ & - & $\mathrm{O}(0,00 \%)$ & - \\
\hline $51 \%$ to $75 \%$ & $\mathrm{O}(0,00 \%)$ & - & $\mathrm{O}(0,00 \%)$ & - \\
\hline $76 \%$ to $100 \%$ & $2(9,52 \%)$ & $-3,03-22,07$ & $2(2,63 \%)$ & $-0,96-6,22$ \\
\hline \multicolumn{5}{|l|}{ Outflows } \\
\hline Crisis Audit & $19(90,48 \%)$ & $77,92-103,03$ & $22(28,95 \%)$ & $19,39-38,51$ \\
\hline ०\% to $25 \%$ & $2(9,52 \%)$ & $-3,03-22,07$ & $1(1,32 \%)$ & $-1,24-3,88$ \\
\hline $26 \%$ to $50 \%$ & 8 (38.09\%) & $17,32-58,85$ & $7(9.21 \%)$ & 2,71-15,71 \\
\hline $51 \%$ to $75 \%$ & $4(19.05 \%)$ & $2,25-35,84$ & 9 (11.84\%) & 4,57-19,10 \\
\hline $76 \%$ to $100 \%$ & $5(23.80 \%)$ & $5,59-42,02$ & $5(6.58 \%)$ & $1,00-12,27$ \\
\hline
\end{tabular}

Table 2: AGENCIES STUDY - Types of Audits ordered by Customers

Source: own elaboration

Among 'dircoms' we noted the high percentage (56.57\%) that did not answer the question about the most used types of audits ${ }^{3}$ in the preliminary investigation, as opposed to evaluative research answers, in which the participation grew, remaining virtually stable compared to the average number of responses obtained previously in the questionnaire.

3 Definitions and typologies of public relations and communication audits are available in Stacks (2011: 14-15); Cuenca (2011); and Marca (2011: 92-96). 
In preliminary research, typologies of audits preferred by 'dircoms' were the publicity audit (81.40\%) and the crisis audit (79.07\%), followed closely by the opinions audit $(69.77 \%)$ and the events audit $(67.44 \%)$. The least used were attitudes audits $(11.63 \%)$, which leaves perceptions audits in an intermediate position (39.53\%). In all cases the percentage of usage occasions was at the higher fringe (76.0\% to $100 \%)$, -although the number of respondents was very low-, except for the audits of publicity and events, that were above the $25.0 \%$, both in previous and subsequent research.

Also in evaluative research we see the prevalence of the choice of 'dircoms' for the audits of publicity (98.58\%) and events (74.94\%), followed at great distance by crisis audits $(68.42 \%)$ and an even greater one by reviews audits $(48.68 \%)$. Remain in last place the audits of perceptions (22.37\%) and attitudes (5.26\%).

If we compare both columns in Table 1, we observe that the response rates were higher for 'dircoms' in evaluative research, to the detriment of the preliminary Outputs. This reality does not position participants in a really good place of the methodological domain in strategic research, since differences should tend to zero. In the remaining ones -Outtakes, Outcomes and Outflows- it is noteworthy that the preliminary investigation exceeded the evaluative. We observed that, in percentage terms, the participants preferred those audits related to the preliminary research and the final evaluation of the Outputs (publicity and events), followed by Outflows (crisis), also in two stages -preliminary and final- of the strategic research process.

Among agencies (Table 2), results in both types of research are not coincidents, as only 21 responses were obtained $(27.63 \%)$ on the use of the preliminary research, against the $100 \%$ declaring to develop some type of evaluative research. But differences between both types of research do not end here: in the preliminary stage, agencies received orders of publicity audits in $76.19 \%$ of cases, and of events audits in the $19.05 \%$, while in the subsequent evaluation phase it increased to maximum the use of publicity audits, that accomplished all of the positive responses (100\%). Event audits go behind narrowly (71.0\% - 93.42\%).

By contrast, in perceptions audits differences between preliminary and evaluative research were zero, achieving a dialogical balance between both of them. And in Outcomes and Outflows, agencies/consultancies reported having received a higher percentage of preliminary evaluative research orders.

The most used audits by agencies/consultancies were those related to final evaluation of the Outputs (100\% publicity audits, and $93.42 \%$ event audits), followed by Outflows in the previous stage ( $90.48 \%$ crisis audits).

\section{Comparative Analysis with the ECM-European Communication Monitor}

We observe abundant correlations between results of our research and some of the trends noted in various editions analyzed of the ECM (2007, 2008, 2009, 2010, 2011, 2012), described above: 
- In the use of evaluative research it appears a prevalence of measuring the appearance of messages in the media (Outputs), followed by the evaluation of business objectives (Outflows).

- When measuring their business, we evidence a preponderance of external evaluation (Outputs), both among European and Spanish professionals.

- Participants in the 2009 ECM reported having identified the main needs for improvement in technical learning, especially on research and measurement. From the results of our comparative analysis, the data suggest the same alignment of training deficiencies among Spanish professionals.

- Many results of the several items discussed in the study of agencies, compared to those of their customers, could confirm that "agencies provide an ability to quantify results (17.9\%)", and that "the agencies think that they are engaged because of strategic ad/or market insight and experience $(83.0 \%)$ but only $41.6 \%$ of their clients do so", although, in Spain, it can be also applied that agencies overestimate their abilities in all areas of strategic support (2008 ECM).

- According to the 2008 ECM, the applied research investment was very low in Europe. The correlation with the responses of Spanish professionals in our study remains at identical levels five years later.

- The long-term cooperation between the professional sector and academic research was very low in Europe, according to the 2008 ECM. Data show that the Spanish situation is similar in 2012, as if academic researchers would mediate with professionals, the methodological violations, identified in the canonical strategic process of our double study, would not probably exist.

- Participants at 2010 ECM asserted that "We help adjust organisational strategies"; that "We build immaterial assets"; and that "We feel responsible for helping to define business strategies by adding the communicative dimension to strategy formulation" (+1,8\% compared to 2009). Despite the absence of empirical confirmation, since our questionnaires did not provide specific questions on these 'items', the same idea could have been expressed by Spanish participants, although the methodological lacks identified could seriously question the veracity and rigor of these claims.

- The 2010 ECM showed that $69.7 \%$ of managers attribute to themselves the responsibility of the planning and the evaluation of their interventions (the $74.4 \%$ in Southern Europe), and in planning procedures we detected that the situation could still improve, since the data suggest a basically instrumental level. Correlation exists with the Spanish professional scene, derived from our findings.

- The alignment of the Spanish and European professionals is also correlated in strategic aspects of professional practice (2011 ECM): "PR is no longer regarded as a suitable label for the profession compared to other concepts: $61.3 \%$ Strategic Communication". $90.8 \%$ of participants said that "We focus and supporting business goals by planning and executing Communication" (+5.4\% compared to 2010 and $+6 \%$ compared to 2009) and that "We feel responsible for helping to define business strategies" ( $+8,3 \%$ compared to 2010 and $+10,1 \%$ compared to 2009 ), although methodological deficiencies observed in Spain may question the quality of the implementation of these practices.

- The 2012 ECM shows that European participants state that there are gaps in terms of understanding of professional practice by their superiors (84.0\%) and difficulties to test the impact of communication in the corporate objectives (75.0\%), constituting the main barriers to professionalization and the major unresolved challenges. We venture the hypothesis that, in this way, it could be established, perhaps, a vicious circle: the top management, unable to define the functions of the area, hire professionals who do not have adequate skills to demonstrate the efficacy of some ill-conceived strategic interventions and worse evaluated, so that the dominant coalition of companies and organizations would not understand what communication could contribute to corporate objectives and, thus, 'ad nauseam'. We can guess that, logically, insufficiently trained people can only be hired as functional directors if the top management does not knows the roles that they must develop in front of the department, often contributing to promote a professional intrusion that perpetuates and aggravates the situation. This could be the reason why, decades elapsed, the situation does not improve in the functional area responsible for managing communication, and why it usually equates to the one of their homologues in line of the other functional areas. 
- The 2012 ECM concluded that "For decades now, Communications Management and public relations is transforming itself from an operational practice of preparing, producing and disseminating Communications materials into a full strategic Management function, which includes speaking as well as consulting as well as executing", although the poor application of necessary tools for adequately professionalizing this transition in Spain still appears distant, in response to the trends observed in our studies.

- An orientation to the professional practice, more operational -tactical- than strategic, causes that among European participants: "Although the majority of productive time still goes to operational communication (talking to colleagues and media, writing texts, monitoring, organising events, etc.), this does not account for more than $37 \%$ of typical week. Managing activities related to planning, organising, leading staff, evaluating strategies, justifying spending and preparing for crises takes $29 \%$ of the time" and that "media relations professionals perform the largest portion of operational work, while practitioners engaged in governmental relations, public affairs and lobbying spend more time for reflective activities". The data suggest that there is a similar correlation between our participants in Spain.

- Professional deficiencies identified in our studies in Spain come endorsed and correlated with the following quote from 2012 ECM: "These changes in the environment are requiring communication professionals to reconceptualise and reorganise that they do. [...] As professional communicators are moving from mostly operational to more managerial, educational and reflective levels, building competencies and skills is the next big challenge both for individuals and organisations".

\section{Conclusions and Future Research}

We have just seen that, broadly, the Spanish situation defined by our double study does not differ too much of the European, regarding to the development of the strategic 'praxis' of customers and providers of communication and public relations services, and that there is still a long way to go in order to achieve levels of excellence in the old continent, including the Spanish state.

Among the most employed audits by agencies/consultancies, publicity audit stands out in a highly remarkable way, being a possible indicator that this typology, directly linked to the flagship product offered by suppliers to their customers and purchased by them, establishes the prevalence of a press office service delivery framework, and that participants that mostly order it are more press officers than genuine functional managers, since that activity, with an operational-tactical orientation, possibly occupies a dominant position in their departments.

This assumption was contrasted when the data show that publicity audits were the most used ones by customers and suppliers in their evaluative stage. The net interest shown by participants for everything related to the appearance of messages in the form of editorial content in the media and their accountability seems to be a sign that, when something is valued, people invest on it as needed, without lacks of budget that could suppose an obstruction. Hence, publicity audits do not only occupy the top of the audits used ranking, but they are also placed in an unusual position of excellence, since most of participants reported using it systematically.

However, the measurement and the evaluation should be done comprehensively, i.e., not only of the messages published in the form of editorial content in the media and on social networks, but of everything related to publics and stakeholders of an 
organization (perceptions, attitudes, opinions, behaviours, and relationships), which still appears to be a great challenge to perform for both Spanish groups studied, up to reach the major form.

In our study the data suggest the prevalence of Outputs in publicity actions, although in any activity can be measured and evaluated both the quantity and the quality of the Output, as it is also shown as predominantly reflected in relation to event organization in our research.

Except in the field of Outflows and specifically in the field of crisis communication, where there was also a remarkable prevalence, we observed that the measurement of the remaining results (Outtakes and Outcomes) occupies a markedly lower interest in both groups, which is consistent with audits use routines which are necessary to carry out the measurement and the evaluation, which are requested by clients and developed by service providers at much lower percentages.

From all the above, the data suggest that the professionals involved, according to the audits used and their percentages of use, are still significantly away from the relational dimension of the discipline postulated by Bruning and Ledinghan (1999: 157-170) and Ledinghan and Bruning (1998: 55-65; 2000: xi-xvii), in the sense that the traditional view of the management function as a merely responsible for the communication management has led to the more mature and evolved version of management of relations with publics (Public Relations vs. Publics Relations), which uses communication strategically, so that, for this, professionals should focus their efforts on developing long-term relationships between organizations and their key publics, rather than relying solely on symbolic activities to improve the image.

The data show that although our European and Spanish practitioners sample, today, still contemplates the Press Agent or Public Information Model -unidirectional and persuasive practices- (Gruning \& Hunt, 1984: 34), communication and PR profession has evolved into the relationships between organizations and their key audiences, at the detriment of the simple transmission of messages to passive and mass and nonsegmented audiences of the mass media (in consistence with Black, 1999; Newson, Turk \& Kruckeberg, 2004), that place the "praxis" only on a tactical level (Gruning \& Repper, 1992: 118; Rodríguez-Polo, 2011: 2-3; Oliveira, 2012: 34-35).

Consequently, then, our Research Question (RQ1) "Which are the most common types of audits used by the directors of communication and its agencies/consultancies in Spain?" has been clearly answered, so that the professional stage derived from the statements of both groups in this regard is not particularly flattering in respect to the trends identified on the capabilities of strategic development and planning that may overcome the anchor prevalence on the Press Agents stage, in what refers to the fieldworks carried out by these two Spanish actors of the professional practice of communication and public relations management.

To verify its possible evolutions in the future, the strategic practice of both groups and the mode and the quality of routines developed in their professional relations from our perspective of analysis, we propose to repeat both studies every four years, in order 
to establish a permanent Observatory in the service of the two main actors of the profession and, also, of the specialized scientific community on this object of study, who may be interested in having evolutional empirical data.

\section{REFERÊNCIAS}

ADECEC [http://www.adecec.com/].

AMEC-Association for Measurement and Evaluation of Communication (2010). Barcelona Declaration of Measurement Principles, available at http://amecorg.com/2012/06/barcelona-declaration-of-mea surement-principles/.

Black, S. (1994). Las Relaciones Públicas: un factor clave de gestión ( $2^{2}$ ed.), Barcelona: Hispano Europea.

Broom, G.M. \& Dozier, D.M. (1990). Using Research in Public Relations: Applications to program Management. New Jersey: Prentice-Hall.

Bruning, S.D. \& Ledingham, J.A. (1999). 'Relationships between organizations and publics: Development of a multi-dimensional organization-public relationship scale', Public Relations Review, 25(2): 157-170.

Cuenca, J. (2011). El análisis de la calidad de las relaciones en el ámbito de las Relaciones Públicas. Aplicación de un modelo global de auditoría de Relaciones Públicas a la sociedad municipal 22@ del Ayuntamiento de Barcelona, Tesis doctoral, Barcelona: Facultad de Comunicación Blanquerna, Ramon Llull University, available at http://hdl. handle.net/10803/51765.

Cuenca, J. (2012). Las auditorías de las Relaciones Públicas. Barcelona: UOC.

Cutlip, S., Center, A.H. \& Broom, G.M. (2011). Relaciones Públicas Eficaces (8 $8^{\text {th }}$ ed.). Barcelona: Gestión 2000.

Dircom [http://www.dircom.org/presentacion/presentacion.html].

Grunig, J. E., \& Hunt, T. (1984). Managing Public Relations. Fort Worth, TX: Harcourt Brace.

Grunig, J. E. \& Repper, F. C. (1992). 'Strategic Management, Publics and Issues', en J.E. Grunig (Ed.) (1992), Excellence in Public Relations and Communication Management. Hillsdale, N): Lawrence Erlbaum, pp. $117-157$.

IPR-Institute for Public Relations (2000). Guidelines and Standards for Measuring Effectiveness in Public Relations Programs and Activities, Gainesville, FL: IPR-Institute for Public Relations, available at http:// www.instituteforpr.org/topics/effectiveness-programs-activiti es/.

Jeffrey, L. \& Brunton, M. (2011). 'Developing a framework for communication management competencies', Journal of Vocational Education and Training, 63(1): 57-75.

L’Étang, J. (2009). Relaciones Públicas. Conceptos, práctica y crítica. Barcelona: UOC.

Ledingham, J. A. \& Bruning, S. D. (1998). 'Relationship Management in Public Relations: Dimensions of an Organization-Public Relationship', Public Relation Review, 24(1): 55-65.

Ledingham, J. A. \& Bruning, S. D. (2000). 'Introduction: background and current trends in the study of relationship management', en J.A. Ledingham \& S.D. Bruning (Eds.) (2000), Public Relations as Relationship Management: A Relational Approach to the Study and Practice of Public Relations. Mahwah, NJ: Lawrence Erlbaum, pp. xi-xvii. 
Marca, G. (2011). La evaluación en los modelos de planificación estratégica de las Relaciones Públicas. Análisis comparativo del uso de la evaluación de la comunicación en las redes hospitalarias de los modelos sanitarios de España, el Reino Unido y Estados Unidos, Tesis doctoral, Tarragona (Spain): Universidad Rovira i Virgili, available at http:// hdl.handle.net/10803/51765.

Matilla, K. (2010). 'Pasado, presente y futuro del 'Dircom' en España', FISEC-Estrategias, Facultad de Ciencias Sociales de la Universidad Nacional de Lomas de Zamora, 14, 4: 3-24.

Matilla, K. (2009). Conceptos Fundamentales en la Planificación Estratégica de las Relaciones Públicas. Barcelona: UOC.

Matilla, K. (2008). Los Modelos de Planificación Estratégica en la Teoría de las Relaciones Públicas. Barcelona: UOC.

Matilla, K. (2007). Aportaciones para un modelo global de Planificación Estratégica en Relaciones Públicas $\gamma$ Comunicación Integral. Análisis de un caso: el uso de los modelos de Planificación Estratégica en algunas agencias y consultoras de Relaciones Públicas y Comunicación, Tesis doctoral, Barcelona: Facultad de Comunicación Blanquerna, Universidad Ramon Llull, available at http://hdl. handle.net/10803/9222.

Matilla, K. \& Marca, G. (2012). 'The Accountability Gap: the Use of Preliminary and Evaluative Research in Spain', Public Relations Review, 38(5): 825-830.

Matilla, K. \& Marca, G. (2011). 'La función estratégica del Dircom en España en 2010', Revista Internacional de Relaciones Públicas, 1(2), Jul.-Dic, available at http://revistarelacionespublicas.uma.es/index.php/ revrrpp/article/view/19.

Moreno, A., Verhoeven, P., Tench, R. \& Zerfass, A. (2009). “European Communication Monitor 2009. An institutionalized view of how public relations and communication management professionals face the economic and media crises in Europe", Public Relations Review, 36(2): 97-104.

Moreno, A., Verhoeven, P., Tench, R. \& Zerfass, A. (2010). “European Communication Monitor 2009. El desarrollo de la profesión de Relaciones Públicas y gestión de la comunicación estratégica en Europa", Razón y Palabra, 72, available at http://redalyc.uaemex.mx/src/inicio/ArtPdfRed. jsp?iCve=199514906045.

Newsom, D., Turk, J.V. \& Kruckeberg, D. (2004). This is PR: the realities of Public Relations. Belmont, CA: Thomson.

Oliveira, A. (2012). Los públicos en la etapa de investigación de la Planificación Estratégica de las Relaciones Públicas. Estudio de los públicos en las empresas productoras, distribuidoras y comercializadoras de gas natural y energía eléctrica en España, Tesis doctoral, Tarragona: Facultad de Comunicación, Universidad Rovira i Virgili, available at http://www.tdx.cat/bitstream/handle/10803/97217/Tesis\%20. pdf? sequence $=1$.

Robina, X., Amisha, M.M. \& Gregory, A. (2006). "Evaluation in Use: The Practitioner View of Effective Evaluation", PRism Online Journal, 4(2): 1-11.

Rodríguez-Polo, X.R. (2011). "Los efectos de la comunicación de masas de Josep T. Klapper”, Razón y Palabra, 75: 1-17.

Seitel, F.P. (2002). Teoría y Práctica de las Relaciones Públicas, Madrid: Pearson Educación.

Sha, B.L. (2011), "2010 Practice Analysis: Professional Competencies and Work Categories in Public Relations Today", Public Relations Review, 37(3): 187-196.

Stacks, D.W. (2011). Primer of Public Relations Research, New York: Guilford Press. 
Tench, R. (2012). "ECOPSI Benchmarking Preliminary Report”, in Report for the Europe Communication Skills and Innovation Program, available at www.leedsmet.ac.uk./ecoopsi.

Torres y Carrera (2011). El sector de las Relaciones Públicas en España. Análisis económico. Madrid: Puesto Base.

Xifra, J. (2005). Planificación estratégica de las Relaciones Públicas. Barcelona: Paidós.

Zerfass, A., Van Ruler, B., Rogojinaru, A., Verçiç, D. \& Hamrefors, S. (2007), European Communication Monitor 2007, Brussels (Belgium): EACD, EUPRERA, available at http://www.zerfass.de/ecm/index.htm.

Zerfass, A., Tech, R., Verhoeven, P., Verçiç, D. \& Moreno, A. (2008), European Communication Monitor 2008, Brussels (Belgium): EACD, EUPRERA, available at http://www.zerfass.de/ecm/index.htm.

Zerfass, A., Tech, R., Verhoeven, P., Verçiç, D. \& Moreno, A. (2009). European Communication Monitor 2009, Brussels (Belgium): EACD, EUPRERA, available at http://www.zerfass.de/ecm/index.htm.

Zerfass, A., Tech, R., Verhoeven, P., Verçiç, D. \& Moreno, A. (2010). European Communication Monitor 2010, Brussels (Belgium): EACD, EUPRERA, available at http://www.zerfass.de/ecm/index.htm.

Zerfass, A., Tech, R., Verhoeven, P., Verçiç, D. \& Moreno, A. (2011). European Communication Monitor 2011, Brussels (Belgium): EACD, EUPRERA, available at http://www.zerfass.de/ecm/index.htm.

Zerfass, A., Verçiç, D., Verhoeven, P., Moreno, A. \& Tech, R. (2012). European Communication Monitor 2012, Brussels (Belgium): EACD, EUPRERA, available at http://www. zerfass.de/ecm/index.htm.

$* * *$

Received: 13-07-2014

Accepted: 09-10-2014 